\begin{tabular}{|l|l|l||}
\hline \multicolumn{2}{|c|}{ PublisherInfo } \\
\hline \hline PublisherName & $:$ & BioMed Central \\
\hline \hline PublisherLocation & $:$ & London \\
\hline \hline PublisherImprintName & $:$ & BioMed Central \\
\hline \hline
\end{tabular}

\title{
Dodo genetics
}

\begin{tabular}{|l|l|l||}
\hline \multicolumn{2}{|c|}{ ArticleInfo } \\
\hline \hline ArticleID & $:$ & 4412 \\
\hline \hline ArticleDOI & $:$ & $10.1186 /$ gb-spotlight-20020301-01 \\
\hline \hline ArticleCitationID & $:$ & spotlight-20020301-01 \\
\hline \hline ArticleSequenceNumber & $:$ & 78 \\
\hline \hline ArticleCategory & $:$ & Research news \\
\hline ArticleFirstPage & $:$ & 1 \\
\hline \hline ArticleLastPage & $:$ & 2 \\
\hline \hline & & RegistrationDate : 2002-3-1 \\
\hline ArticleHistory & $:$ & OnlineDate \\
\hline \hline ArticleCopyright & $:$ & BioMed Central Ltd2002-1 \\
\hline \hline ArticleGrants & $:$ & \\
\hline \hline ArticleContext & $:$ & 130593311 \\
\hline \hline
\end{tabular}




\section{Jonathan B Weitzman}

Email: jonathanweitzman@hotmail.com

The dodo (originally Didus ineptus and renamed Raphus cucullatus) is a mysterious, now extinct, bird that has been difficult to position in evolutionary trees. In the March 1 Science, Beth Shapiro and researchers at the University of Oxford, UK, report a genetic analysis of the evolutionary history of the dodo (Science 2002, 295:1683). They examined DNA sequences amplified from the mitochondrial genomes of 37 species of pigeons and doves, including the dodo and another flightless bird called the solitaire. They used the data to construct a phylogenetic tree and conclude that the dodo and the solitaire are indeed sister taxa, nested with pigeons within the family Columbidae. Using external fossil calibrations, they were able to estimate that the dodo and the solitaire separated about 25.6 million years ago.

\section{References}

1. Science, [http://www.sciencemag.org]

2. University of Oxford, [http://www.oxford.ac.uk] 